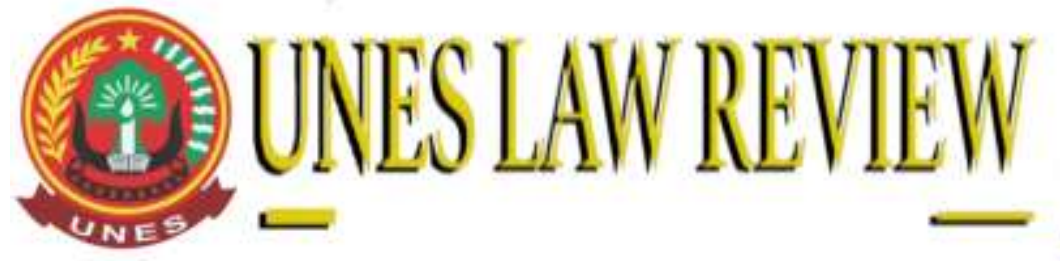

$+6282287504359$

+6282287504359

https://review-unes.com/ (2)

uneslawreview@gmail.com

DOI: https://doi.org/10.31933/unesrev.v3i3

Diterima: 11/03/2021, Diperbaiki: 20/03/2021, Diterbitkan: 21/04/2021

\title{
APLIKASI PIDANA TERHADAP KETERAMPILAN YANG MELAKUKAN PENGOPERASIAN KAPAL NON-LAUT YANG MENYEBABKAN KORBAN \\ (Analisis Putusan Nomor 117 / Pid.Sus / 2015 / PN Sgm dan Putusan Nomor 69 / Pid Sus / 2015 / PN Kdl)
}

\author{
Ade Ridwan \\ Program Magister Ilmu Hukum, Universitas Ekasakti, Padang, Indonesia \\ Email: aderidwan71@gmail.com \\ Corresponding Author: Ade Ridwan
}

\section{ABSTRACT}

Law No. 17 of 2008 concerning Shipping which has mandated that the ships operated must meet maritime requirements. Article 117 paragraph (1) letter a of Law No. 17 of 2008 concerning Shipping states that shipworthiness is one of the requirements for the safety and security of water transportation, therapy in fact there are still many skippers who sail ships that are not seaworthy, causing material and life losses, as in Decision No. 117 / Pid.Sus / 2015 / PN Sgm and Decision No. 69 / Pid Sus / 2015 / PN Kdl. Based on the discussion and analysis, it can be concluded that: First, the punishment imposed on Decision No. 117 / Pid.Sus / 2015 / PN Sgm is 4 months in prison while in Decision No. 69 / Pid Sus / 2015 / PN Kdl, the defendant was sentenced to 8 months in prison. The difference is based on the difference in losses arising from the actions of each defendant. Apart from that, the punishment imposed was not appropriate and did not fulfill the sense of justice because it was very far from the maximum limit. Second, the Judge's Consideration in Imposing Crime Against the Captain Who Operates a Ship Not Seaworthy Which Cause Casualties in Decision No. 117 / Pid.Sus / 2015 / PN Sgm and Decision No. 69 / Pid Sus / 2015 / PN Kdl are juridical considerations, non-juridical considerations, namely things that are burdensome and relieve the defendant, instructions, and facts that emerge during the trial.

Keywords: Application, Skills, Ship Operations, Victims 


\begin{abstract}
ABSTRAK
Undang-Undang No. 17 Tahun 2008 tentang Pelayaran yang telah mengamanatkan bahwa kapal yang dioperasikan harus memenuhi syarat kelaiklautan. Pasal 117 ayat (1) huruf a UndangUndang Undang-Undang No. 17 tahun 2008 tentang Pelayaran menyebutkan bahwa kelaiklautan kapal merupakan salah satu persyaratan keselamatan dan keamanan angkutan perairan, terapi pada kenyataannya masih saja banyak nakhoda yang melayarkan kapal yang tidak laiklaut sehingga menyebabkan kerugian materiil dan jiwa, seperti pada Putusan No. 117/Pid.Sus/2015/PN Sgm dan Putusan No. 69/Pid Sus/2015/PN Kdl. Berdasarkan pembahasan dan analisis, dapat disimpulkan bahwa: Pertama, Pidana yang dijatuhkan pada Putusan No. 117/Pid.Sus/2015/PN Sgm adalah 4 bulan pejara sementara itu pada Putusan No. 69/Pid Sus/2015/PN Kdl terdakwa dijatuhkan putusan 8 bulan penjara. Perbedaan tersebut didasari pada perbedaan kerugian yang timbul akibat perbuatan masing-masing terdakwa. Terlepas dari itu, Pidana yang dijatuhkan kurang tepat dan kurang memenuhi rasa keadilan karena sangat jauh dari batasan maksimum. Kedua, Pertimbangan Hakim dalam Menjatuhkan Pidana Terhadap Nahkoda yang Mengoperasikan Kapal Tidak Laik Laut yang Menyebabka Korban Jiwa Pada Putusan No. 117/Pid.Sus/2015/PN Sgm dan Putusan No. 69/Pid Sus/2015/PN Kdl adalah pertimbangan yuridis, pertimbangan non-yuridis yaitu hal-hal yang memberatkan dan meringankan terdakwa, petuntuk, serta fakta yang muncul selama persidangan.
\end{abstract}

Kata Kunci: Aplikasi Pidana, Keterampilan, Pengoperasian Kapal, Korban

\title{
PENDAHULUAN
}

Jika kita cermati, dalam beberapa tahun terkahir ini kecelakaan pelayaran tidak pernah berkurang. Bahkan, sebab kecelakaan laut tersebut seperti berulang-ulang. Penyebab dari kecelakaan antara lain adalah cuaca buruk, berlebihan beban atau kapal yang tidak memenuhi syarat kelaikan jalan. Dalam pelayaran di Indonesia, setidaknya terdapat dua penyebab kecelakaan. Pertama, kondisi aramada pelayaran itu sendiri. Kapal-kapal yang digunakan sebagai alat transportasi laut dibuat tanpa adanya standar keselamatan yang baik. Selain itu, armada kapal di Indonesia merupakan kapal bekas yang dibeli dari negara lain. Perawatannya pun juga dilakukan di bawah standar. Umumnya, umur kapal bekas yang dipakai dalam pelayaran di Indonesia biasanya telah tua dan tidak laik laut lagi.

Meningkatnya penggunaan transportasi laut juga diiringi dengan meningkatnya angka kecelakaan transportasi laut. Saat ini kecelakaan kapal seperti telah menjadi suatu hal yang biasa di Indonesia. Hal ini dibuktikan dengan banyaknya pemberitaan tentang kecelakaan kapal yang terus terjadi, diantaranya:

1. Kecelakaan Kapal Motor Penumpang Manggala, pada tanggal 29 Juni 1998 dalam pelayaran dari Pelabuhan Ferry Merak yang mengangkut 428 orang penumpang dan 56 unit kendaraan tujuan Pelabuhan Ferry Bakauheni. Kapal mengalami kerusakan mesin kemudi dan kemudian kandas di Pantai Ujung Pulau Rimak Balak, Lampung. Dalam peristiwa tersebut tidak ada korban jiwa, semua penumpang dapat dievakuasi dengan selamat dan kendaraan di dalam Ferry dapat dipindahkan ke kapal lain (ship to ship transfer) dengan dibantu 2 (dua) kapal tunda.

2. Kecelakaan Kapal Motor Nusantara Pasifik pada tanggal 16 Desember 1999 yang 
tenggelam di perairan antara Pulau Masalembo dan Pulau Kalamban. Ketika dalam pelayarannya dari pelabuhan Tanjung Perak Surabaya tujuan Samarinda dengan muatan general cargo dalam peti kemas berukuran 20 inch sebanyak 60 teus. Kapal mengalami kerusakan mesin induk. Dalam kecelakaan ini tidak memakan korban jiwa, tetapi kapal beserta muatannya tidak dapat diselamatkan.

3. Kecelakaan Kapal Motor Sentosa Penyeberangan yang terjadi pada tanggal 18 Desember 2006 di tengah perjalannya dari Tanjung Pinang ke Pulau Natuna di Kepulauan Riau.

4. Kecelakaan Kapal Motor Asita III yang terjadi pada tanggal 18 Oktober 2007. Kapal mengalami kecelakaan dengan sedikitnya 31 orang meninggal dunia dan 35 orang lainnya hilang (M. Y. Jinca, 2007:2-3).

5. Kecelakaan Kapal Motor Sinar Madinah yang tenggelam di perairan Laut Selatan Desas Hu'u, Kabupaten Dompu, Provinsi Nusa Tenggara Barat pada tanggal 11 Juli 2007.

6. Kecelakaan Kapal Motor Levina, jurusan Tanjung Priok - Pangkal Balam, Bangka, yang tenggelam pada tanggal 22 Februari 2007.

7. Kecelakaan Kapal Motor Penumpang Belanak, jenis ferry milik PT. Angkutan Sungai Danau dan Penyeberangan, yang menabrak speed boat milik nelayan di perairan Pantai Barat pada tanggal 31 Agustus 2008.

8. Kecelakaan Kapal Dumai Ekspress 10 pada tanggal 22 November 2009 di Kepulauan Riau. Dari kecelakaan tersebut lebih dari 200 (dua ratus) orang penumpang dapat diselamatkan, dan 21 (dua puluh satu) orang meninggal dunia.

9. Terbakarnya KM Mutiara Sentosa di perairan Maslembu, Kabupaten Sumenep, Provinsi Jawa Timur pada tanggal 19 Mei 2017, yang menyebabkan 5 (lima) penumpang tewa dan 24 (dua puluh empat) lainnya hilang.

10. Terbakarnya KM Zahro Express di perairan Kepulauan Seribu, Jakarta pada tanggal 1 Januari 2017, yang menyebabkan 23 penumpang meninggal dunia.

11. Terbaliknya Kapal Cepat Anugrah Express di perairan Sungai Tanjung Selor, Kalimantan Utara pada tanggal 1 Januari 2018. Dalam insiden ini 8 (delapan) orang meninggal dunia.

12. Terbaliknya Kapal Feri Kayong Utara di perairan tanjung Api-Api, Banyuasin, Sumatera Selatan, pada tanggal 20 Februari 2018. Kapa ini mengangkut 31 pengumpang, delapan truk, satu mobil pribadi dan dua sepeda motor.

13. Kecelakaan Kapal Cepat yang membawa 12 penumpang dari Distrik Tabonji menuju Kota Merauke di Perairan Wamal, Distrik Tubang, Kabupaten Merauke, Papua pada tanggal 2 Mei 2018. Kecelakaan ini menyebabkan 11 orang hilang.

14. Kecelakaan KM Arista pada tangal 13 Juni 2018 di Danau Toba Sumatera Utara. 164 orang hilang dan 3 orang meninggal dunia.

15. Kandasnya Kapal Motor Lesatari Maju pada tanggal 3 Juli 2018 yang mengangkut penumpang dari Buluumba ke Selayar, Sulawesi Selatan, di perairan Pantai Pabeddilang. Kecelakaan ini menyebabkan 34 orang meninggal dunia.

16. Tenggelamnya Kapal Motor (KM) Famili 010 GT 20 yang berpenumpang 12 orang pada 
tanggal 29 Januari 2020. Dalam kecelakaan tersebut, seorang Anak Buah Kapal (ABK) dikabarkan hilang, sementara 11 ABK ditambah nahokda kapal berhasil diselamatkan.

17. Sebelumnya juga terjadi kecelakaan kapal wisata yang membawa 24 (dua puluh empat) penumpang yang terbalik dihantam ombak pesar di perairan Pualu Angso Duo, Kota Pariaman. Kapal tersebut tenggelam akibat dihantam ombak besar ketika mendekati dermaga Pulau Angos Duo, yang menyebabkan seluruh penumpang jatuh ke laut. Akibat insiden tersebut seorang penumpang meninggal dunia.

Hal ini cukup bertetangan dengan Undang-Undang No. 17 Tahun 2008 tentang Pelayaran yang telah mengamanatkan bahwa kapal yang dioperasikan harus memenuhi syarat kelaiklautan. Pasal 117 ayat (1) huruf a Undang-Undang No. 17 tahun 2008 Tentang Pelayaran menyebutkan bahwa kelaiklautan kapal merupakan salah satu persyaratan keselamatan dan keamanan angkutan perairan.

Selanjutnya pada ayat (2) disebutkan bahwa kelaiklautan kapal sebagaimana dimaksud pada ayat (1) huruf a wajib dipenuhi setiap kapal sesuai dengan daerah pelayarannya yang meliputi:

1. Keselamatan kapal.

2. Pencegahan pencemaran dari kapal.

3. Pengawakan kapal.

4. Garis muat kapal dan pemuatan.

5. Kesejahteraan Awak Kapal dan kesehatan penumpang.

6. Status hukum kapal.

7. Manajemen keselamatan dan pencegahan pencemaran dari kapal, dan

8. Menajemen keamanan kapal.

Kemudian pada ayat (3) disebutkan bahwa pemenuhan setiap persyaratan kelaiklautan kapal sebagaimana dimaksud pada ayat (1) dibuktikan dengan sertifikat dan surat kapal. Secara lebih khusus kelaiklautan kapal diatur di dalam Bab IX Undang-Undang No. 17 Tahun 2008 tentang Pelayaran. Di dalam Pasal 138 ayat (2) disebutkan: sebelum kapal berlayar, nahkoda wajib memastikan bahwa kapalnya telah memenuhi persyaratan kelaiklautan dan melaporkan hal tersebut kepada Syahbandar.

Beberapa norma di atas secara jelas telah memberikan pemahaman kepada kita bahwa untuk dapat dioperasikannya sebuah kapal maka harus memenuhi persyratan kelaiklautan. Disamping itu kewajiban nahkoda untuk memastikan kepalnya telah memenuhi persyaratan kalaiklautan juga akan berimplikasi hukum manakala kewajiban tersebut tidak dilaksanakan dengan baik.

Penyebab kedua adalah operasional dari penggunaan kapal-kapal tersebut. Penyebab ini muncul karena lemahnya pengawasan terhadap standar keselamatan pelayaran. Selain itu, banyaknya jumlah kapal ke Laut Cina Selatan terus ke Laut Pasifik atau sebaliknya yang banyak menyebabkan terjadinya persitwa kandasnya kapal atau saling berbenturan antar kapal serta penabrakan rambu-rambu yang terpasang (Kuntoro, 2000:1). Selain faktor-faktor tersebut di atas, masih terdapat faktor lain yang menyebabkan kecelakaan kapal, diantaranya kesalahan manusia. 
Pihak-pihak yang dapat bertanggung jawab dalam kecelakaan kapal adalah perusahaan pengangkut dan nahkoda kapal. Dalam Pasal 40 ayat (1) Undang-Undang No. 17 Tahun 2008 tentang pelayaran menyebutkan: Perusahaan angkutan di perairan bertanggungjawab terhadap keselamatan dan keamanan penumpang dan/atau barang yang diangkut.

Selain perusahaan pengangkutan, pihak lain yang bertanggungjawab adalah nahkoda dari kapal tersebut. Dalam Pasal 341 Kitab Undang-Undang Hukum Dagang disebutkan bahwa nahkoda adalah pemimpin kapal, sehingga sebagai pemimpin kapal diharapkan nahkoda dapat memenuhi pertanggungjawabannya seperti yang diisyaratkan oleh undang-undang. Selanjutnya dalam Pasal 342 KUHD juga disebutkan tanggung jawab nahkoda, yakni:

Nahkoda diwajibkan bertindak dengan kecakapan dan kecermatan serta kebijaksaan yang sedemikian sebagaimana diperlukan untuk melakukan tugasnya. Sekaitan dengan tanggung jawab nahkoda, berdasarkan Putusan Nomor 117/Pid.Sus/2015/PN Sgm, hakim menyatakan bahwa terdakwa Irwan Alias Iwan Bin Haris Dg. Rurung terbukti secara sah dan meyakinkan bersalah melakukan tindak pidana "Nahkoda melayarkan kapalnya sedangkan yang bersangkutan mengetahui bahwa kapal tersebut tidak laik laut yang mengakibatkan kematian seseorang dan kerugian harta benda". Hakim menjatuhkan pidana terhadap terdakwa selama 2 (empat) bulan.

Sementara pada Putusan Nomor 69/Pid Sus/2015/PN Kdl, hakim menyatakan bahwa terdakwa Max Donald Koanggong Bin Sander terbukti secara sah dan meyakinkan bersalah melakukan tindak pidana "Melayarkan kapal yang tidak laik laut yang mengakibatkan kematian dan kerugian harta benda". Hakim menjatuhkan hukuman pidana kepadanya selama 8 (delapan) bulan dan denda sejumlah Rp. 5.000.000,--

Berdasarkan kedua Putusan di atas, penulis melihat adanya disparitas sikap hakim dalam menjatuhkan putusan, padahal tindak pidana yang dilakukan oleh kedua terdakwa adalah sama, tetapi dalam hal penjatuhan hukuman terdapat perbedaan yang signifikan. Terlepas dari hal itu, penulis juga menilai bahwa hukuman yang dijatuhkan kepada keduanya terlalu ringan sehingga kurang memberikan efek jera.

Berdasarkan uraian di atas, maka penulis memandang perlu untuk melakukan penelitian hukum terkait pengenaan sanksi pidana bagi nahkoda dalam kecelakaan kapal dengan judul "Penerapan Pidana Terhadap Nahkoda Yang Melakukan Pengoperasian Kapal Tidak Laik Laut Yang Mengakibatkan Korban Jiwa (Analisis Putusan No. 117/Pid.Sus/2015/PN Sgm dan Putusan No. 69/Pid Sus/2015/PN Kdl)"

\section{METODE PENELITIAN}

Penelitian ini merupakan penelitian deskriptif. Metode pendekatan dalam penelitian ini hanya menggunakan metode pendekatan yuridis normatif. Pendekatan penelitian ini dilakukan melalui melalui penelitian hukum in concreto. Dalam penelitian ini data yang digunakan hanya data sekunder yang mencakup bahan hukum primer, yang merupakan bahan hukum utama yang akan dijadikan rujukan dalam penelitian ini. Teknik pengumpulan data yang digunakan adalah Studi Kepustakaan (library research), yaitu pengumpulan data dari bahan hukum. Data yang diperoleh dianalisis secara kualitatif. Data yang telah dianalisis kemudian disajikan dalam bentuk deskriptif. 


\section{HASIL DAN PEMBAHASAN}

\section{Penerapan Pidana terhadap Nahkoda yang mengoperasikan kapal tidak laik laut yang} menyebabkan korban jiwa pada Putusan No. 117/Pid.Sus/2015/PN Sgm dan Putusan No. 69/Pid Sus/2015/PN Kdl

Pemidanaan dalam konteks peradilan di Indonesia memiliki tiga dimensi utama, yakni: pidana, sistem pemidanaan dan teori pemidanaan. Ketiga dimensi itu akan mengarahkan bagaimana seharusnya penjatuhan pidana oleh hakim dalam proses peradilan pidana (Lilik Mulyadi, 2008:6). Pidana hakikatnya mengandung unsur-unsur:

1. Pengendaan penderitaan atau nestapa akibat-akibat lain yang tidak menyenangkan.

2. Diberikan dengan sengaja oleh orang atau badan yang mempunyai kekuasaan (oleh yang berwenang).

3. Dikenakan kepada seseorang yang telah melakukan tindak pidana menurut undangundang.

Kemampuan bertanggungjawab diatur di dalam ketentuan Pasal 44 ayat (1) KUHP mengatur: Barang siapa melakukan perbuatan yang tidak dapat dipertanggungjawabkan kepadanya karena jiwanya cacat dalam pertumbuhan atau terganggu karena cacat, tidak dipdidana.

Hal yang mendasari pertanggungjawaban tindak pidana adalah pemahaman bahwa setiap manusia dianugerahi Tuhan Yang Maha Esa dengan akal budi dan nurani yang memberikan kepadanya kemampuan untuk membedakan yang baik dan yang buruk yang akan membimbing dan mengarahkan sikap dan perilaku dalam menjalani kehidupannya. Dengan akal budi dan nuraninya itu, maka manusia memiliki kebebasan untuk memutuskan sendiri perilaku atau perbuatannya. Selain untuk mengimbangi kebebasan, manusia memiliki kemampuan untuk bertanggung jawab atas semua tindakan yang dilakukannya.

Pertanggungjawaban pidana Nahkoda yang melayarkan kapal tidak laiklaut sehingga menyebabkan korban jiwa telah di atur di dalam Undang-undang No. 17 Tahun 2008 tentang Pelayaran. Secara jelas disebutkan bahwa Jika perbuatan melayarkan kapal yang tidak laiklaut mengakibatkan kematian seseorang dan kerugian harta benda dipidana dengan pidana penjara paling lama 10 (sepuluh) tahun dan denda paling banyak Rp. 1.500.000.000,- (satu milyar lima ratus juta rupiah).

Penerapan pidana oleh hakim dalam Putusan No. 117/Pid.Sus/2015/PN Sgm dan Putusan No. 69/Pid Sus/2015/PN Kdl memiliki perbedaan yang signifikan dan kurang memenuhi unsur keadilan. dalam Putusan No. 117/Pid.Sus/2015/PN Sgm hakim sama-sama memutuskan bahwa kedua terdakwa bersalah melanggar Pasal 302 ayat (3). Tetapi di dalam amar putusannya terdapat perbedaan pidana yang diberikan. Pada Putusan No. 117/Pid.Sus/2015/PN Sgm hakim memutuskan memberikan pidana penjara terhadap Irwan selama 4 (empat) bulan, sementara itu pada Putusan No. 117/Pid.Sus/2015/PN Sgm hakim menjatuhkan pidana penjara kepada Max Donald Koanggong selama 8 (delapan) bulan. Jika dicermati, Irwan dan Max Donald merupakan 
nahkoda yang sama-sama melayarkan kapal tidak laik laut tetapi terdapat perbedaan pidana hingga 50\% diantara keduanya.

Padahal di dalam Surat Dakwaan Penuntut Umum mendakwa terdakwa Iwan dengan Pasal 302 ayat (3) Undang-Undang No. 17 Tahun 2008 tentang Pelayaran atau Pasal 359 KUHP. Sementara Max Donald Koanggong didakwa dengan Pasal 302 ayat (3) Undang-Undang No. 17 Tahun 2008 tentang Pelayaran atau Pasal 359 KUHP pada dakwaan pertama, Pasal 302 ayat (1) Undang-Undang No. 17 Tahun 2008 tentang Pelayaran atau Pasal 359 KUHP pada dakwaan kedua, dan Pasal 359 KUHPidana.

Penetapan pidana yang diberikan oleh hakim kepada kedua terdakwa meskipun memiliki perbedaan besar $(50 \%)$ dalam pandangan penulis masih terasa kurang pas dan kurang memenuhi rasa keadilan. Hal ini mengingat ancaman maksimal yang ditetapkan di dalam Pasal 302 ayat (3) adalah pidana penjara paling lama 10 (sepuluh) tahun dan denda paling banyak Rp. 15.000.000,00 (lima belas juta rupiah), sementara pidana yang dijatuhkan kepada Irwan adalah 4 (empat) bulan dan kepada Max Donald Koanggong adalah 8 (delapan) bulan. Jika dikalkulasikan, pidana yang diberikan kepada Irwan hanya 3\% Sementara itu kepada Max Donald Koanggong sebesar 7\% dari jumlah pidana maksimum yang ditetapkan.

Sekaitan dengan hal ini, penulis menilai bahwa substansi hukum yang dibangun kurang lengkap, pembuat undang-undang tidak menetapkan batas minimum pidana di dalam Pasal 302 ayat (3) Undang-Undang No. 17 Tahun 2008 tentang Pelayaran. Hal ini menyebabkan penerapan pidana bagi nahkoda yang melayarkan kapal yang tidak laiklaut terasa kurang memberikan memenuhi rasa keadilan, tidak member efek jera dan kurang evektif dalam meningkatkan kesadaran hukum terkait keselamatan pelayaran bagi nahkoda.

Padahal Secara umum kita telah mengetahui bahwa salah satu hal yang ingin dicapai di dalam hukum pidana adalah penanggulangan kejahatan. Sudarto mengemukakan bahwa suatu usaha yang rasional dari masyarakat dalam menanggulangi kejahatan dapat disebut dengan politik criminal atau kebijakan criminal. Politik criminal dapat juga diartikan dalam arti sempit, lebih luas, dan paling luas (Sudarto, 1981:113).

Tujuan pemidanaan saat ini tidak hanya dapat dilihat sebagai aspek pembalasan (absolute) ataupun aspek pencegahan (relative). Barda Nawawi Arief mengungkapkan perkembangan tujuan pidana sebagai berikut (Barda Nawawi Arief, 2009:14):

1. Dilihat dari aspek perlindungan terhadap kejahatan, maka tujuan pidana adalah penanggulangan kejahatan.

2. Dilihat dari aspek perlindungan terhadap pelaku, maka tujuan pidana adalah perbaikan si pelaku (mengubah tingkah laku).

3. Dilihat dari aspek perlindungan terhadap penyalahgunaan saknsi/reaksi, maka tujuan pidana adalah mengatur/membatasi kesewenangan penguasa dan warga masyarakat.

4. Dilihat dari aspek perlindungan terhadap keseimbangan kepentingan/nilai yang terganggu, maka tujuan pidana adalah memelihara/memulihkan keseimbangan masyarakat. 
Dalam sistem hukum pidana menurut KUHP sebenarnya telah dikenal batas hukuman minimum, yakni dalam hal lamanya hukuman penjara dan hukuman kurungan. Menurut Wirjono Prodjodikoro, soal perbedaan pokok antara hukuman penjara dan hukuman kurungan mengatakan bahwa: Menurut Pasal 12 ayat (2) KUHP, lamanya hukuman penjara adalah sekurang-kurangnya (minimum) satu hari dan selama-lamanya lima belas tahun dilampaui dalam hal gabungan tinndak-tindak pidana, revedivice, atau dalam hal berlakunya Pasal 53 KUHP (Wirjono Prodjodikoro, 2003:181).

Sementara itu Menurut Pasal 18 ayat (1) KUHP, lamanya hukuman kurungan (hectenis) adalah sekurang-kurangnya satu hari dan selama-lamanya satu tahun, dengan kemungkinan maksimum ini dinaikkan menjadi satu tahun empat bulan dengan aturan-aturan yang sama.

Sedangkan R. Soesilo (1991:38) menjelaskan bahwa pasal ini menetapkan umum lamanya hukuman penjara sementara minimum satu hari dan maksimum lima belas tahun. Sehari ialah tempo yang lamanya dua puluh empat jam. Maksimum umum 15 tahun itu dapat dilampaui sampai selama-lamanya 20 tahun dalam hal antara lain kejahatan yang menurut pilihan hakim sendiri boleh dihukum mati, penjara seumur hidup dan penjara sementara, dan dalam hal 15 tahun itu dilampaui, sebab hukuman ditambah karena ada kejahatan atau berulang-ulang membuat kejahatan.

Hal ini kemudian berdampak lebih lanjut kepada putusan yang diberikan oleh hakim. Terlepas dari tempus dan locus maupun actus dan reus nya berbeda, barang jelas bahwa putusan yang diberikan oleh hakim akan selalu berbeda antara satu sama lainnya meskipun Pasal yang didakwakan selalu sama.

Lebih jauh lagi, ketiadaan batasan minimum yang ditetapkan di dalam Undang-Undang Pelayaran terhadap Nahkoda yang melayarkan kapal yang tidak laik laut akan semakin meningkatkan jumlah nahkoda yang tidak peduli dengan ketidaklaiklautan kapal yang pada akhirnya akan meningkatkan jumlah kecelakaan kapal di Indonesia. Sanksi pidana yang diberikan oleh pengadilan tidak akan memberikan pengaruh kepada nahkoda. Pidana yang hanya dalam hitungan bulan saja akan terasa singkat, apalagi harus dipotong dengan masa tahanan yang telah dijalani sebelum putusan pengadilan diucapkan.

Asumsi lain dapat dikemukakan terhadap penerapan pidana yang dilakukan oleh hakim dalam Putusan No. 117/Pid.Sus/2015/PN Sgm dan Putusan No. 69/Pid Sus/2015/PN Kdl yang menjatuhkan pidana sangat jauh dari batas maksimum adalah prinsip kebebasan kehakiman yang secara langsung diamanatkan oleh konstitusi. Hal ini ditegaskan di dalam Pasal 24 ayat (1) Undang-Undang Dasar Negara Republik Indonesia Tahun 1945 yang menyebutkan bahwa kekuasaan kehakiman merupakan kekuasaan yang merdeka untuk menyelenggarakan peradilan guna menegakkan hukum dan keadilan.

Kendati demikian, prinsip kebebasan kehakiman bukanlah kebebasan semena-mena untuk menjatuhkan hukuman terhadap seseorang atas dasar kemauan hakim, tetapi kebebasan yang dimaksudkan di dalam konstitusi adalah kebebasan untuk tidak terikat, tidak dipengaruhi atau intervensi oleh siapapun atau lembaga manapun dalam memutus suatu perkara. 
Lebih lanjut menurut ketentuan Pasal 1 Undang-Undang No. 4 Tahun 2004 tentang Kekuasaan Kehakiman. Kata bebas memiliki konotasi makna tidak boleh terikat oleh apa pun dan tidak ada tekanan dari siapa pun. Bebas juga berarti suatu tindakan tidak boleh digantungkan kepada apa pun atau siapa pun. Bebas juga memiliki arti leluasa untuk berbuat apa pun sesuai dengan keinginan dari kebebasan itu sendiri. Apabila kata bebas disifatkan kepada hakim, sehingga menjadi kebebasan hakim dalam menjalankan tugasnya sebagai hakim, maka dapat memberikan pengertian bahwa hakim dalam menjalankan tugas kekuasaan kehakiman tidak boleh terikat dengan apa pun dan/atau tertekan oleh siapa pun, tetapi leluasa untuk berbuat apa pun. Memaknai arti kebebasan semacam itu dinamakan kebebasan individual atau kebebasan ekstensial (Firman Floranta Adonara, 2015:221).

Dengan demikian, prinsip kebebasan kehakiman dalam pandangan penulis bukanlah alasan yang tepat untuk dijadikan alasan penerapan pidana yang jauh dari batas maksimum. Penulis melihat bahwa kecelakaan kapal karena kelaiklautan kapal harus dipandang sebagai hal yang sangat serius oleh pemerintah dan seluruh stakeholder terkait. Apalagi kecelakaan kapal karena ketidaklaiklautan yang menyebabkan hilangnya nyawa seseorang.

Seharusnya hakim dengan prinsip kekuasaan kehakiman yang mandiri dalam menerapkan pidana bagi nahkoda yang melayarkan kapal tidak laik laut sehingga menyebabkan orang lain meninggal memandang hakekat kehidupan atau nyawa sebagai anuegrah Tuhan Yang Maha Esa yang tidak dapat diganti ataupun dibeli. Hal inipun sudah dilindungi secara konstitusional di dalam Pasal 28 A UUD 1945 yang menyebut setiap orang berhak untuk hidup serta berhak mempertahankan hidup dan kehidupannya.

Jika dibandingkan dengan beberapa peraturan perundang-undangan lainnya, misalnya di dalam Pasal 46 ayat (1) Undang-Undang No. 10 Tahun 1998 tentang Perubahan Atas UndangUndang No. 7 Tahun 1992 tentang Perbankan yang menetapkan batas minimum penjara sekurang-kurangnya 5 (lima) tahun bagi Barang siapa menghimpun dana dari masyarakat dalam bentuk simpanan tanpa izin usaha dari Pimpinan Bank Indonesia. Pidana yang dilakukan oleh setiap orang sesuai pasal ini hanya tidak memiliki izin (hanya bersifat administrative). Atau di dalam Ketentauan Pasal 122 ayat (1) Undang-Undang No. 2 Tahun 2004 tentang Penyelesaian Perselisihan Hubungan Industrial yang menetapkan batas minimum sanksi pidana kurungan paling singkat 1 (satu) bulan bagi siapa saja yang melanggar ketentuan Pasal 12 ayat (1), Pasal 22 ayat (1) dan ayat (3), Pasal 47 ayat (1) dan ayat (3), Pasal 90 ayat (2), Pasal 91 ayat (1) dan ayat (3). Dan masih banyak lagi peraturan perundang-undangan yang tindak pidananya tidak menyebabkan meninggalnya orang lain ditetapkan batas minimum penerapan pidana.

Tetapi ketentuan Pasal 302 ayat (3) Undang-Undang No. 17 Tahun 2008 tentang Pelayaran tidak menetapkan batasan minimum pengenaan pidana. Padalah nahkoda yang mengemudikan kapal tersebut mengetahui bahwa perbuatannya yang mengemudikan kapal tidak laik laut akan menimbulkan kerugian bagi penumpangnya, bukan hanya kerugian materiil, tetapi juga kehilangan nyawa. 


\section{Pertimbangan Hakim dalam Menjatuhkan Pidana Terhadap Nahkoda yang Mengoperasikan Kapal Tidak Laik Laut yang Menyebabka Korban Jiwa Pada Putusan No. 117/Pid.Sus/2015/PN Sgm dan Putusan No. 69/Pid Sus/2015/PN Kdl}

Pertimbangan hakim merupakan salah satu aspek terpenting dalam menentukan terwujudnya nilai dari suatu putusan hakim yang mengandung keadilan (ex aequo et bono) dan mengandung kepastian hukum, di samping itu juga mengandung manfaat bagi para pihak yang bersangkutan sehingga pertimbangan hakim ini harus disikapi dengan teliti, baik, dan cermat. Apabila pertimbangan hakim tidak teliti, baik, dan cermat, maka putusan hakim yang berasal dari pertimbangan hakim tersebut akan dibatalkan oleh Pengadilan Tinggi atau Mahkamah Agung (Mukti Arto,2004:140).

Dalam pemeriksaan suatu perkara juga memerlukan adanya pembuktian, dimana hasil dari pembuktian itu akan digunakan sebagai bahan pertimbangan dalam memutus perkara. Pembuktian merupakan tahap yang paling penting dalam pemeriksaan di persidangan. Pembuktian bertujuan untuk memperoleh kepastian bahwa suatu peristiwa/fakta yang diajukan itu benar-benar terjadi, guna mendapatkan putusan hakim yang benar dan adil. Hakim tidak dapat menjatuhkan suatu putusan sebelum nyata baginya bahwa peristiwa/fakta tersebut benarbenar terjadi, yakni dibuktikan kebenaranya, sehingga nampak adanya hubungan hukum antara para pihak.

Dalam suatu putusan hakim yang baik, biasanya pertimbangannya selalu mengandung pertimbangan yuridis dan pertimbangan non yuridis.

\section{Pertimbangan Yuridis}

Pertimbangan yurids merupakan pertimbangan hakim yang didasarkan pada fakta-fakta yang terungkap di dalam persidangan dan oleh undang-undang telah ditetapkan sebagai hal yang harus dimuat di dalam putusan. Pertimbangan yuridis diantaranya:

a. Dakwaan penuntut umum

b. Keterangan saksi

c. Keterangan terdakwa

d. Barang-barang bukti

e. Pasal-pasal dalam undang-undang tindak pidana terdapat di dalam dakwaan penuntut umum

Dakwaan yang didakwakan oleh Penuntut Umum terhadap iwan di dalam Putusan No. 117/Pid.Sus/2015/PN Sgm adalah dakwaan alternative. Penuntut umum menggunakan Pasal 302 ayat (3) Undang-Undang No. 17 Tahun 2008 tentang Pelayaran, yang menentukan jika perbuatan sebagaimana dimaksud pada ayat (1) mengakibatkan kematian seseorang dan kerugian harta benda dipidana dengan pidana penjara paling lama 10 (sepuluh) tahun dan denda paling banyak Rp. 1.500.000.000,- (satu milyar lima ratus juta rupiah) atau Pasal 359 KUHP yang menyebutkan: barang siapa karena kesalahannya menyebabkan matinya seseorang dihukum penjara selama-lamanya lima tahun atau kurungan selama-lamanya satu tahun.

Sama halnya dengan Putusan No. 117/Pid.Sus/2015/PN Sgm , pada Putusan No. 69/Pid Sus/2015/PN Kdl penuntut umum juga menggunakan dakwaan alternative. Pasal yang digunakan 
oleh Penuntut Umum adalah Pasal 302 ayat (3) Undang-Undang No. 17 Tahun 2008 tentang Pelayaran, Pasal 302 ayat (1) Undang-Undang No. 17 Tahun 2008 tentang Pelayaran, dan Pasal 359 KUHP pada dakwaan ketiga.

Berdasarkan fakta yang terungka di persidangan, kedua terdakwa sama-sama melanggar Pasal 302 ayat (3) Undang-Undang No. 17 Tahun 2008 tentang Pelayaran, oleh karenanya dakwaan lainnya tidak perlu dibuktikan pada sidang pengadilan.

Unsur-unsur yang terdapat di dalam Pasal ini adalah: "unsur setiap orang/Nahkoda", unsur melayarkan kapalnya yang bersangkutan mengetahui bahwa kapal tersebut tidak laik laut" dan "unsur mengakibatkan kematian seseorang dan kerugian harta benda".

Pertama, unsur setiap orang/Nahkoda. Pasal 1 angka 41 Undang-Undang No. 17 Tahun 2008 tentang Pelayaran menyebutkan bahwa Nahkoda adalah salah seorang dari awak kapal yang menjadi pemimpin tertinggi di kapal dan mempunyai wewenang dan tanggung jawab tertentu sesuai dengan ketentuan peraturan perundang-undangan.

Fakta persidangan yang ditemukan di pengadilan, Irwan dan Max Donald Koanggong terbukti sebagai subyek hukum yang dapat dimintakan pertanggungjawaban pidana terhadap perbutan yang telah dilakukannya. Irwan merupakan subyek hukum " setiap orang" (naturlijk person) yang tidak terganggu oleh penyakit terus-menerus atau sementara, tidak mengalami cacat dalam pertumbuha serta tidak tergaggu karena hypnotism, amarah, pengaruh alam bawah sadar, melindur, mengigau, ngidam.

Pembuktian Irwan sebagai terdakwa pada Putusan No. 117/Pid.Sus/2015/PN Sgm didasarkan pada keterangan-keterangan yang diberikan oleh saksi diantaranya Irfan alias Cimmong, Bayu Irwanto, Baso Dede, Rismawati, Salawati, Abdul Kahar Dg. Painga, Muhammad Aspah, di depan sidang pengadilan yang mengatakan bahwa Irwan adalah orang yang menahkodai kapal yang mengalami kecelakaan pada tanggal 22 Februari 2015 yang menyebabkan meninggalnya 3 (tiga) orang penumpang yang dimuatnya.

Sementara itu penetapan Max Donald Koanggong sebagai terdakwa pada Putusan No. 69/Pid Sus/2015/PN Kdl berdasarkan keterangan yang diberikan oleh Saksi Suyanto yang menunjuk Max Donald Koanggong sebagai Nahkoda pengganti Nahkoda Dede yang pulang ke Palembang untuk menjenguk ayahnya yang sedang sakit. Sementara itu keterangan dari Crew lainnya yang berjumlah 8 (delapan) orang membenarkan bahwa Max Donald Koanggong adalah orang yang menahkodai kapal pada saat berlayar, tetap mereka tidak diberitahukan bahwa adanya pergantian Nahkoda dari Dede kepada Max Donald Koanggong, dan pergantian itupun dilakukan tanpa pemberitahuan kepada Syahbandar.

Sesuai ketentuan Pasal 184 ayat (1) huruf a j.o Pasal 185 ayat (1) dan ayat (4) Kitab Undang-Undang Hukum Acara Pidana (KUHAP) yang menentukan bahwa salah satu alat bukti yang sah ialah keterangan saksi yang disampaikan di sidang pengadilan yang memiliki hubungannya satu dengan yang lainnya sedemikian rupa, sehingga dapat membenarkan adanya suatu kejadian atau keadaan tertentu.

Dengan demikian, keterangan-keterangan saksi yang saling bersesuaian telah menjadi alat bukti yang sah untuk dapat menetapkan Irwan dalam Putusan No. 117/Pid.Sus/2015/PN Sgm 
dan Max Donald Koanggong dalam Putusan No. 69/Pid Sus/2015/PN Kdl sebagai orang yang bersalah dan dapat mempertanggungjawabkan perbutannya yang melayarkan kapal tidak laik laut yang menyebabkan orang lain meninggal dunia dan .

Sekaitan dengan pembuktian, meskipun Penuntut Umum di dalam surat dakwaannya pada Putusan No. 117/Pid.Sus/2015/PN Sgm tidak mengajukan alat bukti bahwa yang bersangkutan adalah seorang nahkoda, yakni adanya Ijazah atau dokumen kelulusan atau dokumen lainnya yang menyatakan bahwa Irwan adalah seorang Nahkoda tetapi pasal ini menentukan "setiap orang/Nahkoda". Dalam penggunaan rumusan kata demikian berarti hakim hanya perlu membuktikan salah satu dari kata tersebut, baik setiap orang maupun setiap nahkoda.

Sementara itu pada Putusan No. 69/Pid Sus/2015/PN Kdl Penuntut Umum mengajukan bukti Surat Persetujuan Berlayar No: K 1/KM 17/1010/IX/2015 yang menjelasan bahwa Max Donald Koanggong adalah Crew yang berijazah ANT V dan berkedudukan sebagai Mualim I.

Kedua, melayarkan kapalnya yang bersangkutan mengetahui bahwa kapal tersebut tidak laik laut. Fakta yang terungkap selama persidangan dari keterangan saksi-saksi yang saling bersesuaian serta keterangan dari Irwan sendiri diketahui bahwa kapal yang dilayarkannya tidak dilengkapi dengan surat izin untuk mengemudikan kapai / perahu sebagai nahkoda / juru mudi untuk melakukan pelayaran atau perjalanan dan memuat 20 orang serta 16 unit sepeda motor. Sedangkan pada kasus Max Donald Koanggong, meskipun ia dapat melakukan pelayaran dikarenakan dirinya Berijazah ANT V dan berkedudukan sebagai Mualim I, yang berarti ia adalah orang pertama yang akan menggantikan Nahkoda apabila Nahkoda tidak dapat melayarkan kapal, tetapi ia tidak melaporkan kepada Syahbandar bahwa dirinya ditunjutk sebagai Nahkoda untuk menggantikan Dede. Dalam hal ini Max Donald Koanggong tidak mendapatkan Izin Berlayar dari Syahbandar.

Undang-Undang No. 17 tahun 2008 tentang Pelayaran tidak menyebutkan secara limitative bahwa seseorang atau nahkoda yang melayarkan kapal tanpa izin berlayar dapat dikategorikan sebagai ketidaklaiklautan. Di dalam Pasal 219 ayat (1) disebutkan bahwa Surat Persetujuan Berlajar merupakan persyaratan yang waib dimiliki oleh setiap orang atau nahkoda yang akan melayarkan kapal.

Berdasarkan Undang-Undang No. 17 Tahun 2008 tentang Pelayaran disebutkan bahwa unsur kelaiklautan kapal yang harus terpenuhi dalam setiap pelayaran adalah: keselamatan kapal, pencegahan pencemaran dari kapal, pengawakan kapal, garis muat kapal dan pemuatan, kesejahteraan awk kapal dan kesehatan penumpang, status hukum kapal, manajemen keselamatan dan pencegahan pencemaran dari kapal, dan manajemen keamanan kapal.

Penerbitan Surat Izin Berlayar di atur di dalam Peraturan Menteri Perhubungan No. PM. 82 Tahun 2014 tentang Tata Cara Penerbitan Surat Persetujuan Berlayar, dan Peraturan Menteri Perhubungan No. PM 39 Tahun 2017 tentang Pendaftaran dan Kebangsaan Kapal. Kewenangan penerbitan Pas Kecil dan Pas Sungai Danau yang semula merupakan kewenangan Pemeirntah Daerah Kabuapten/Kota diubah menjadi kewenangan Pemerintah Pusat (Syahbandar), yang 
pelaksanaannya dilakukan oleh KSOP / UPP dan Surat Persetujuan Berlayar harus diterbitkan oleh Syahbandar.

Jika dihubungkan antara Surat Persetujuan Berlayar dengan ketidaklaiklautan kapal, maka penulis menilai hal tersebut secara implicit tersirat di dalam Pasal 135 Undang-Undang No. 17 Tahun 2008 tentang Pelayaran. Pasal ini menyebutkan bahwa setiap kapal wajib diawaki oleh awak kapal yang memenuhi persyaratan kualifikasi dan kompetensi sesuai dengan ketentuan nasional dan internasional.

Pendapat tersebut bersesuaian dengan apa yang disampaikan oleh Ahli Capt Hadi Supriyono pada Putusan No. 69/Pid Sus/2015/PN Kdl yag menyebutkan bahwa kapal (TB. Freight Express 1 menarik BG. Freight Express 01) yang berlar dapat dikatakan tidak laik laut dalam hal pengawakan dikarenakan tidak adanya nahkoda Dede, karena sesuai sijil yang seharusnya menjadi nahkoda adalah Dede. Tetapi sebagai nahkoda, Dede tidak dapat mendelegasikan tugas dan wewenangnya kepada Mualim I (Max Donal Koanggong) hanya dengan cara menyuruh saja. Dikarenakan Nahkoda Dede tidak ikut berlayar maka Surat Persetujuan Berlayar yang menyertai pelayaran dari Cierbon menuju Semarang secara otomatis tidak berlaku.

Melalui penjelasan yang disampaikan oleh Ahli Capt Hadi Supriyono, maka dapat dipahami bahwa Surat Persetujuan Berlayar merupakan salah satu unsur yang wajib dipenuhi untuk dapat berlayar. Ini berarti bahwa tanpa adanya persetujuan berlayar, maka setiap kapal yang berlayar tanpa adanya Surat Persetujuan Berlayar dapat dikategorikan sebagai tidaklaiklaut. Hal ini juga berlaku bagi kapal yang dilayarkan oleh Irwan yang tidak Surat Persetujuan Berlayar atau Surat Izin melayarkan kapal sebagai nahkoda.

Ketiga, mengakibatkan kematian seseorang dan kerugian harta benda. Fakta persidangan yang ditemukan dan keterangan saksi-saksi serta keterangan terdakwa sendiri pada Putusan No. 117/Pid.Sus/2015/PN Sgm, diketahui bahwa akibat yang ditimbuilkan atas perbuatan Irwan yang melayarkan kapal tidak laiklaut adalah kerugian harta benda serta jatunya korban jiwa.

Kerugian yang diderita oleh penumpang kapal adalah: Muhammad Aspah berupa barangbarang yang tenggelam senilai sekitar Rp. 350.000- (tiga ratus lima puluh ribu rupiah), Rismawati mengalami kerugian sekitar Rp. 360.000,- (tiga ratus enam puluh ribu rupiah), dan Abd. Kahar DG Paninga mengalami kerugian sekitar Rp. 300.000,- (tiga ratus ribu rupiah).

Sedangkan korban jiwa adalah sebagai berikut:

a. Muh. Rais, sebagaimana Visum et Repertum No. 445.2/350RSUD-SY/III/2015 tanggal 03 Maret 2015 dari RSUD Syekh Yusuf Sunguminasa. Pada saat sampai di Rumah Sakit, korban telah meninggal dunia dengan kondisi mulutnya dan telingan kanan tampak mengeluarkan darah serta lubang hidung sebelah kiri mengeluarkan air.

b. Muh. Fadly, sebagaimana Visum et Repertum No. 445.2/351/RSUD-SY/III/2015 tanggal 03 Maret 2015 dari RSUD Syekh Yusuf Sungguminasa. Keadaan korban pada saat sampai di RSUD sudah meninggal dunia. 
c. Nur Inayah, sebagaimana Visum et Repertum No. 445.2/352/RSUD-SY/III/2015 tanggal 03 Maret 2015 dari RSUD Syekh Yusuf Sungguminasa. Keadaan korban pada saat tiba di RSUD sudah meninggal dunia.

Dibandingkan dengan kecelakaan kapal akibat ketidaklaiklautan kapal yang terjadi pada Putusan Putusan No. 117/Pid.Sus/2015/PN Sgm, jumlah kerugian harta benda dan korban jiwa pada Putusan No. 69/Pid Sus/2015/PN Kdl jauh lebih besar. Kerugian materiil yang timbul akibat perbuatan Max Donald Koanggong lebih kurang sebesar Rp. 200.000.000,00 (dua ratus juta rupiah). Sedangkan jumlah korban jiwa akibat perbuatannya adalah sebanyak 8 (delapan) orang, sebagai berikut:

a. Visum et repertum nomor: KM /473 / IX / 2015 untuk pemeriksaan jenazah a.n Bunjari.

b. Visum et repertum nomor: KM / 438 / IX / 2015 untuk pemeriksaan jenazah a.n Solekan.

c. Visum et repertum nomor: KM / 239 / IX / 2015 untuk pemeriksaan jenazah a.n Sinuwun.

d. Visum et repertum nomor: KM / 440 / IX / 2015 untuk pemeriksaan jenazah a.n Bonjari

e. Visum et repertum nomor: KM / 442 / IX /2015 untuk pemeriksaan jenazah a.n Sapawi

f. Visum et repertum nomor: KM / 442 / IX / 2015 untuk pemeriksaan jenazah a.n Muhson.

g. Visum et repertum nomor: KM / 443 / IX / 2015 untuk pemeriksaan jenazah a.n Suratman.

h. Visum et repertum nomor: KM / 444 / IX / 2015 untuk pemeriksaan jenazah a.n Muhlisin.

\section{Pertimbangan Non-Yuridis}

Pertimbangan non-yuridis merupakan pertimbangan yang tidak bersifat hukum. Pertimbangan non-yuridis pada dasarnya lebih banyak mempertimbangkan faktof-faktof sosiologis. Adapun faktof sosiologis esensinya lebih banyak menekankan kepada kemanfaatan bagi masayrakat. Dalam memutus suatu perkara dan mempertimbangkan layak atau tidak layaknya seseorang dijatuhi pidana, seorang hakim didasarkan oleh keyakinannya dan tidak saja berdasarkan bukti-bukti yang ada.

Pertimbangan non yuridis dalam Putusan No. 117/Pid.Sus/2015/PN Sgm dan Putusan No. 69/Pid Sus/2015/PN Kdl, menurut pandangan peulis hanya dapat dilihat dari dampak yang ditimbulkan serta kondisi terdakwa pada saat melakukan tindakan tersebut:

a. Dampak yang ditimbulkan

Dampak yang ditimbulkan oleh perbuatan kedua terdakwa adalah kerugian harta benda dan meninggalnya orang lain. Kerugian materiil yang terjadi akibat perbuatan Irwan adalah sebesar Rp. 1.010.000,00 (satu juta sepuluh ribu rupiah) dan 3 orang meninggal dunia. 
Sementara itu kerugian materiil yang ditimbulkan oleh Max Donald Koanggoang adalah sebesar Rp. 200.000.000,00 (dua ratus juta rupiah) dan 8 orang meninggal dunia.

Menurut pandangan penulis, hakim juga perlu mempertimbangakan dampak lebih jauh/lanjut akibat meninggalnya orang lain akibat perbuatan terdakwa. Sudah jelas keluarga yang ditinggalkan akan mengalami kesedihan, bahkan trauma untuk menaiki kapal. Bahkan tidak jarang orang yang meninggal tersebut adalah tulang punggung keluarganya.

b. Kondisi terdakwa saat melakukan tindakan tersebut

Kondisi Irwan pada saat perbuatan dilakukan sebenarnya tidak mengetahui tentang aturan garis muat kapal dan pemuatan. Hal ini terlihat dari dakwaan penuntut umum yang menyatakan bahwa Irwan tidak memiliki surat izin untuk mengemudikan kapal/perahu sebagai nahkoda/juru mudi.

Interpretasinya, apabila seseorang tidak memiliki surat izin untuk mengemudikan kapal/perahu sebagai nahkoda/juru mudi, berarti orang tersebut tidak pernah mengikuti pendidikan terkait dengan pelayaran sehingga ia tidak mengetahui tentang garis muat yang harus dipatuhi. Hal ini semakin terlihat ketiak pada saat perjalanan, perahu yang dikemudikannya berjalan dalam keadaan miring yang menyebabkan air masuk ke dalam kapal.

Sementara itu Max Donald Koanggong pada saat melakukan perbuatan tersebut dalam analisis penulis berada di bawah tekanan pekerjaan. Sebagai seorang karyawan pada PT. Freight Express Indonesia dan crew pada kapal BG. Freight Express 01 yang ditarik TB. Freight Express 1, ia akan merasa terbebani apabila menolak perintah yang diberikan oleh atasannya meskipun ia tahu bahwa perintah tersebut tidak sesuai dengan aturan yang berlaku.

Rasa takut terhadap atasan dan kebutuhan ekonomi mendesak yang perlu dipenuhi membuat Max Donald Koanggong menerima mentah-mentah perintah dari atasannya untuk mengemudikan kapal BG. Freight Express 01 yang ditarik TB. Freight Express 1, menggantikan Nahkoda Dede yang pulang ke Pelembang untuk menjenguk ayahnya.

c. Keadaan yang meringankan

Dalam Kamus Besar Bahasa Indonesia daring disebutkan bahwa pengertian "keadaan" adalah: sifat; perihal (suatu benda) atau suasana; situasi yang sedang berlaku, sedangkan yang dimaksud dengan "yang memberatkan dan yang meringankan" adalah yang membuat menjadi berat atau menjadi ringan, dimana berat dan ringan merupakan ukuran, dalam konteks ini, ukuran pidana yang akan dijatuhkan. "Keadaan" atau "circumstance", dalam Black's Law Dictionary diartikan sebagai an accompanying or accessory fact, event, or condition. (sebuah fakta, peristiwa, atau kondisi yang menyertai atau melengkapi). Dalam hal ini "circumstance" bukan merupakan fakta, peristiwa atau kondisi pokok, melainkan yang menyertai atau melengkapi (Dwi Hananta, 2018:90).

Dalam Putusan No. 117/Pid.Sus/2015/PN Sgm hal-hal yang meringankan Irwan adalah: sebelumnya tidak pernah dihukum akibat perbuatan pidana, terdakwa bersikap 
sopan selama proses persidangan, terdakwa mengakui dengan terus terang perbuatannya dan menyesali perbuatannya tersebut, serta terdakwa dengan pihak korban sudah berdamai dan terdakwa beserta keluarganya sudah memberikan bantuan kepada para korban.

Putusan No. 69/Pid Sus/2015/PN Kdl pertimbangan hal yang meringankan bagi Max Donald Koanggong telah berterus terang dan tidak menghambat jalnnya persidangan, terdakwa telah memberikan uang santunan kepada keluarga korban, dan terdakwa belum pernah dihukum.

Pengakuan terdakwa atas kesalahannya dan sikap menyesal yang ditunjukkan terdakwa, sepenuhnya termasuk dalam ranah penilaian subyektif hakim. Namun demikian hal ini dapat dipertimbangkan sebagai keadaan meringankan, dengan pertimbangan bahwa hal tersebut mengurangi tingkat bahayanya terdakwa

Pertimbangan tentang sifat baik terdakwa tersebut selain sesuai dengan ketentuan Pasal 8 Ayat (2) UU RI No. 48 Tahun 2009 tentang Kekuasaan Kehakiman, juga sesuai dengan pendapat Hessick bahwa memberatkan pidana atas dasar sifat jahat (prior bad acts) tetapi menolak meringankan pidana atas dasar sifat baik (prior good acts), menciptakan ketidakseimbangan dalam pemidanaan (Carisa Byrne Hessick, 2008:1161).

Pertimbangan-pertimbangan seperti telah adanya pemberian maaf dari keluarga korban, diberikannya santunan dan pembayaran ganti rugi atas segala kerugian korban, termasuk keadaan meringankan sebagaimana tersebut di atas. Keadaan-keadaan tersebut merupakan upaya pelaku untuk menghilangkan atau mengurangi tingkat keseriusan dari tindak pidana. Pertimbangan-pertimbangan bahwa terdakwa berada dalam keadaan sedemikian rupa sehingga kesalahan administratif yang dilakukannya mengakibatkan terjadinya tindak pidana, sesuai dengan batasan keadaan meringankan. Keadaan-keadaan tersebut berkaitan dengan tindak pidana yang dilakukan, yang mengurangi tingkat keseriusan dari tindak pidananya atau ancaman bahaya dari pelakunya. Pertimbangan tentang keadaan seperti tersebut di atas juga terjadi misalnya dalam perkara kecelakaan lalu lintas. Dimungkinkan kecelakaan lalu lintas terjadi tidak semata-mata akibat kesalahan pelaku, melainkan terdapat pula faktor kesalahan korban, kondisi jalan yang rusak atau marka jalan yang tidak jelas. Hal tersebut dapat dipertimbangkan sebagai keadaan meringankan.

Di samping kedua batasan keadaan meringankan tersebut, dalam kedua putusan tersebut terdapat hal-hal lain yang merupakan pertimbangan dari aspek sosiologis, untuk mencapai kemanfaatan dalam penjatuhan putusan, sebagaimana terlihat dari identitas terdakwa Iwan yang masih berusia muda. Hal ini dipertimbangkan dengan harapan terdakwa masih memiliki kesempatan yang luas untuk memperbaiki diri dan kembali berguna bagi masyarakat. Sementara itu terdakwa Max Donald Koanggog memiliki tanggungan keluarga. Hal ini dipertimbangkan, mengingat pemidanaan tidak semata-mata berdampak pada terdakwa, tetapi juga pada keluarganya yang ditinggalkan selama terdakwa menjalani pidana perampasan kemerdekaan; 
Pada awal-awal bab ini penulis sebelumnya telah menyebutkan bahwa diantara kedua putusan tersebut terdapat perbedaan yang cukup signifikan, bahkan mencapai perbedaan sebesar 50\%. Berdasarkan analisis dan pembahasan yang telah dilakukan, maka penulis berani dan yakin untuk mengatakan bahwa terdapatnya perbedaan antara kedua putusan tersebut disebabkan pertimbangan hakim yang menilai atau melihat besarnya kerugian yang ditimbulkan serta keadaan yang meringankan para terdakwa, sehingga Max Donald Koanggong dipidana dengan pidana penjara selama 8 (delapan) bulan sementara Irwa dipidana selama 4 (empat) bulan penjara.

\section{PENUTUP}

Berdasarkan analisis dan pembahasan, maka dapat penulis simpulkan sebagai berikut:

1. Pidana yang dijatuhkan hakim pada Putusan No. 117/Pid.Sus/2015/PN Sgm adalah 4 bulan penjara sementara itu pada Putusan No. 69/Pid Sus/2015/PN Kdl. Terdakwa dijatuhi pidana 8 bulan penjara. Terdapat perbedaan penerapan Pidana terhadap Nahkoda yang mengoperasikan kapal tidak laik laut yang menyebabkan korban jiwa antara Perbedaan tersebut didasari pada perbedaan kerugian yang timbul akibat perbuatan masing-masing terdakwa. Terlepas dari itu, Pidana yang dijatuhkan kurang pas dan kurang memenuhi rasa keadilan karena sangat jauh dari batasan maksimum Pasal yang didakwakan oleh Penuntut Umum. Hal ini disebabkan substansi Undang-Undang No. 17 Tahun 2008 tentang Pelayaran tidak mengatur batasan minimum penerapan pidana.

2. Pertimbangan Hakim dalam Menjatuhkan Pidana Terhadap Nahkoda yang Mengoperasikan Kapal Tidak Laik Laut yang Menyebabka Korban Jiwa Pada Putusan No. 117/Pid.Sus/2015/PN Sgm dan Putusan No. 69/Pid Sus/2015/PN Kdl adalah pertimbangan yuridis dan pertimbangan non-yuridis. Pertimbangan yuridis terdiri dari Dakwaan penuntut umum, Keterangan saksi, Keterangan terdakwa, Barang-barang bukti dan Pasal-pasal dalam undang-undang tindak pidana terdapat di dalam dakwaan penuntut umum. Sedangkan pertimbangan non-yuridis meliputi dampak yang ditimbulkan oleh perbuatan terdakwa, kondisi terdakwa pada saat melakukan tindak pidana, dan keadaan yang meringankan terdakwa.

\section{DAFTAR PUSTAKA}

M. Y. Jinca, Keselamatan Transportasi Laut dan Penyeberangan, Makalah disampaikan pada Rapat Kerja Nasional Masyarakat Transportasi Indonesia, Semarang, 29 Januari 2007

Kuntoro, Analisis dan Evaluasi Hukum tentang Keselamatan Pelayaran, Badan Pembinaan Hukum Nasional Departemen Kehakiman dan Hak Asasi Manusia, Jakarta, 2000

Lilik Mulyadi, Pergeseran Perspektif dan Praktik dari Mahkamah Agung Republik Indonesia Mengenai Putusan Pemidanaan, Artikel, PN Kepanjen, 2008

Sudarto, Kapita Selekta Hukum Pidana, Penerbit Alumni, Bandung, 1981

Barda Nawawi Arief, Tujuan dan Pedoman Pemidanaan Perspektif Pembaharuan Hukum Pidana Dan Perbandingan Beberapa Negara, Percetakan Oetama, Semarang, 2009 
Wirjono Prodjodikoro, Asas-Asas Hukum Pidana di Indonesia, Refika Aditama, Bandung, 2003

R. Soesilo, Kitab-Undang-Undang Hukum Pidana (KUHP Serta Komentar-Komentarnya Lengkap Pasal Demi Pasal, Politeia, Bogor, 1991

Firman Floranta Adonara, Prinsip Kebebasan Hakim dalam Memutus Perkara Sebagai Amanat Konstitusi, Jurnal Konstitusi, Volume 12, Nomoe 2, Juni 2015

Mukti Arto, Praktek Perkara Perdata pada Pengadilan Agama, Cet V, Pustaka Pelajar, Yogyakarta, 2004

Dwi Hananta, Pertimbangan Keadaan-Keadaan Meringankan Dan Memberatkan Dalam Penjatuhan Pidana, Jurnal Hukum dan Peradilan, Volume 7, Nomor 1 Maret 2018

Carisa Byrne Hessick, Why Are Only Bad Acts Good Sentencing Factors?, Boston University Law Review, Vol. 88; 1109, 2008

https://id.wikipedia.org/wiki/Daftar_kecelakaan_dan_insiden_kapal_di_Indonesia\#2018

https://www.tagar.id/kapal-tenggelam-di-laut-padang-seorang-abk-hilang

https://regional.kompas.com/read/2019/10/26/21071141/kapal-wisata-di-pulau-angsa-duoterbalik-satu-orang-tewas 